\title{
A Journey from the Pool of Chiral Synthetic Building Blocks to Cell- Penetrating Peptides, to a Novel Type of Enzyme - and back
}

\author{
Dieter Seebach*
}

\begin{abstract}
The roles of polyhydroxy-butyrates/alkanoates (PHB/PHA) in biology, for the preparation of chiral building blocks, and as a source of inspiration for the discovery of $\beta$-and $\gamma$-peptides are discussed. The syntheses and structures of $\beta$-peptides are outlined. The prerequisites for mimicking peptide/protein interactions with $\beta$-peptides and two examples are presented. Single terminal $\beta$-amino-acid residues can lead to stabilization of peptides (cf. NTS(8-13)) in plasma. Cell-penetrating $\alpha-L-, \alpha-D-$, mixed $\alpha$-L/D- and $\beta$-oligoarginines (OAs) and -oligoprolines, as well as the mechanism(s) of internalization are compared. Recent studies show that infected erythrocytes, parasitic organisms and mycobacteria are entered by OA-derivatives, which have been employed as transporters of the antibiotic fosmidomycin. While $\beta$-peptides are generally enzymatically stable (for days in mammals), a microorganism (S. xenopeptidilytica) with an Ntn enzyme (3-2W4 BapA) was discovered that cleaves only $\beta$-peptides, and that was applied in preparations of (enantiopure) $\beta$-amino acids and $\beta$-peptides.
\end{abstract}

Keywords: Cell-penetrating peptides · Fosmidomycin · Oligoarginines · Polyhydroxybutyrate $\cdot \beta$-Peptides · Peptidomimetics $\cdot$ Terminal homologation of peptides

\section{Introduction}

The history of peptide chemistry in our group $^{[1]}$ has its origin in the early work on the pool of chiral building blocks ('chiral pool'), [2] when we used 3-hydroxybutanoates $^{[3]}$ and other readily available enantiopure natural products ${ }^{[4]}$ to prepare macrodiolides, ${ }^{[5]}$ chiral dendrimers, ${ }^{[6]}$ and $\alpha$-branched amino acids. ${ }^{[7]}$ Key intermediates in these investigations were, among others, lithium enolates of the general formulae 1-5 ${ }^{[8]}$ (Fig. 1). The most abundant source of $(R)$-3-hydroxybutanoic acid is its polymer (PHB), a microbial storage material and a component of all biological cells, where it is a posttranslational appendix of proteins and a component of complexes with polyphosphate (polyP) and nucleic acids; the results of investigations of PHB over the past decades can be put in a nutshell by the statement "no life on this planet without PHB". [3,9] Fascinated by this role of a simple polyester we searched for structural information to find that the PHB-backbone is extremely flexible in solution, while in the solid state, in phos-

${ }^{*}$ Correspondence: Prof. Dr. D. Seebach

Laboratorium für Organische Chemie der ETH Zürich Wolfgang-Pauli-Strasse 10

$\mathrm{CH}-8093$ Zürich

Tel.: +4144632 2990

E-mail: seebach@org.chem.ethz.ch pholipid bilayers and in complexes with polyP it may adopt an $(M)-2_{1}$ - or a $(P)-3_{1}-$ helical structure ${ }^{[3 \mathrm{c}]}$ (Fig. 2a). Inspection of the 3 -helix led to the idea to replace the chain-bound oxygen by $\mathrm{NH}$ to stabilize the helix by hydrogen bonding. This led to $\beta$-peptides, which indeed, fold to helices in solution (Fig. 2b).

\section{Synthesis}

In between the idea and the discovery of the world of $\beta$-, and later of $\gamma$-peptides (Fig. 3), lay hard-core organic synthesis with a large group of coworkers for many

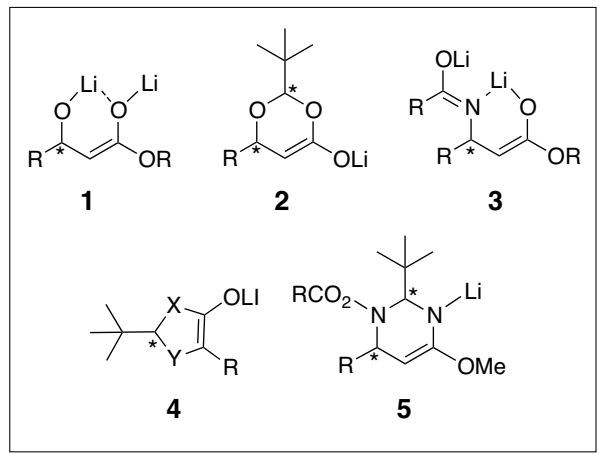

Fig. 1. Chiral Li-enolate derivatives $1-5$ of $\beta$ and $\alpha$-hydroxy, -amino and -mercapto-carboxylic acids. In $4 \mathrm{X}$ may be $\mathrm{O}$ or $\mathrm{NR}, \mathrm{Y}$ can be $\mathrm{O}$, $\mathrm{S}, \mathrm{NCOR}$. * indicates $(R)$ or $(S)$ configuration.

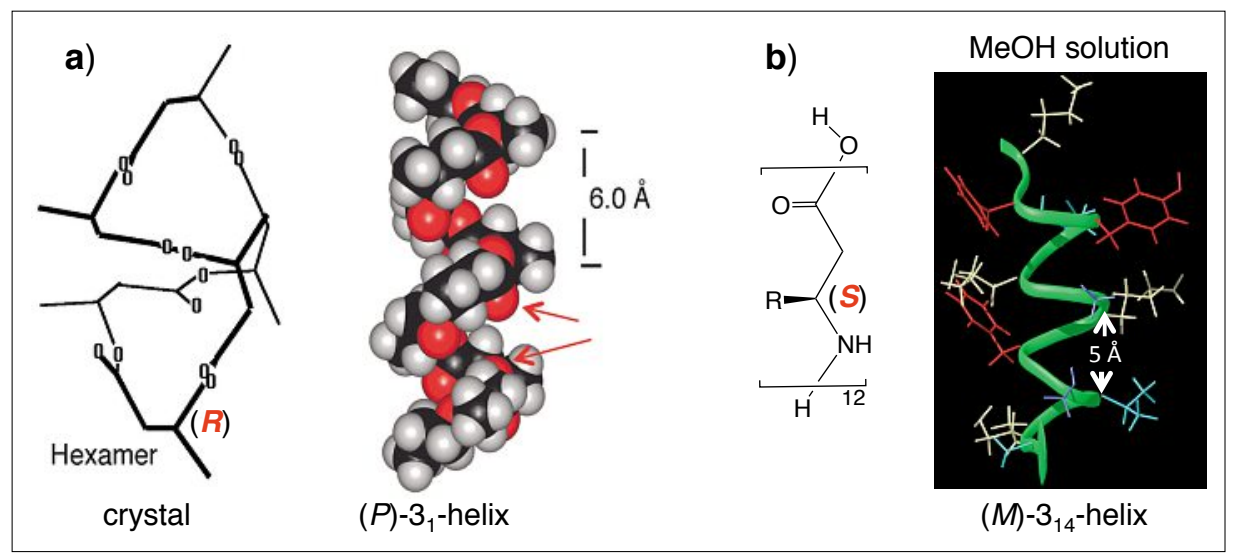

Fig. 2. Helices of $\beta$-hydroxy- and $\beta$-amino-acid oligomers. a) The cyclic HB hexamer has the shape of the number 8 , with $2(P)$-helical pitches, from which the 3 -helix was constructed in silico. ${ }^{[3]}$ b) NMR Structure of a $\beta^{3}$-dodecapeptide in solution. ${ }^{[10]}$ 
years (Fig. 4). ${ }^{[10]}$ There are only four types of $\alpha$-amino acids ((L), (D), $\alpha$-branched such as Aib, and cyclic, such as Pro). In contrast, the $\beta$-amino acids can carry the substituent in the 3- or 2-position, and they may be geminally disubstituted in these positions, or can be cyclic (2-aminocyclopentane or -cyclohexane carboxyclic acid[11]), so that a much larger structural variety results (Fig. 4, center). For the syntheses of the most simple $\beta^{3}$ - and $\beta^{2}$-amino acids we used the Arndt-Eistert homologation and a modified Evans-auxiliary application, respectively. While 18 of the $20 \beta^{3}$-aminoacids with proteinogenic side chains (ready for solid-phase coupling by the Fmoc strategy) are now commercial, most of the $\beta^{2}$-analogs and other types of derivatives have to be tediously prepared as shown for $\beta^{2}$ h-histidine in Fig. 5. ${ }^{[12]}$ The effort was rewarding in many respects.

\section{Structures}

Depending upon the substitution patterns (constitution) and upon the (relative and absolute) configurations of the residues a 'brave new world' of peptide structures ${ }^{[13]}$ was uncovered. As with $\alpha$-peptides

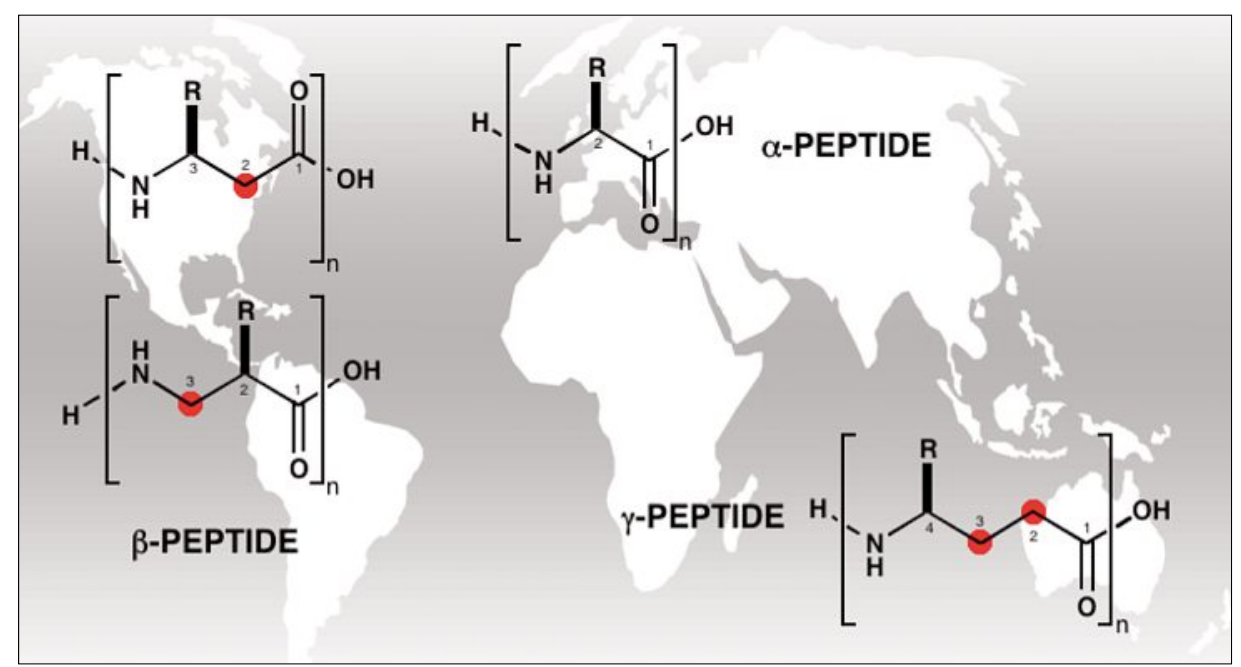

Fig. 3. Relationship between $\alpha$-, $\beta^{3}$-, $\beta^{2}$ - and $\gamma^{4}$-peptides with the proteinogenic side chains R. For further structural variations see Fig. 4. Our research was restricted to peptides consisting of homologated proteinogenic amino acids ${ }^{[10]}$ lacking the back-bone fortifying effects of cyclic aminocarboxylic acid residues. ${ }^{[11]}$

and proteins, there are all the structural elements (strand, sheet, turn, helix) but with different dimensions, distances, polarities, stabilities and exclusivities (Fig. 4). Generally, the secondary structures are more stable than those of the $\alpha$-peptidic counterparts. Also, the sequences can be chosen in such a way that a strand is enforced, which can not aggregate to a sheet, and a sheet structure can be created that can not possibly fold to a turn or helix, while $\alpha$-peptidic chains with very similar sequences may be found either as part of sheets or of helices. There is no mac-

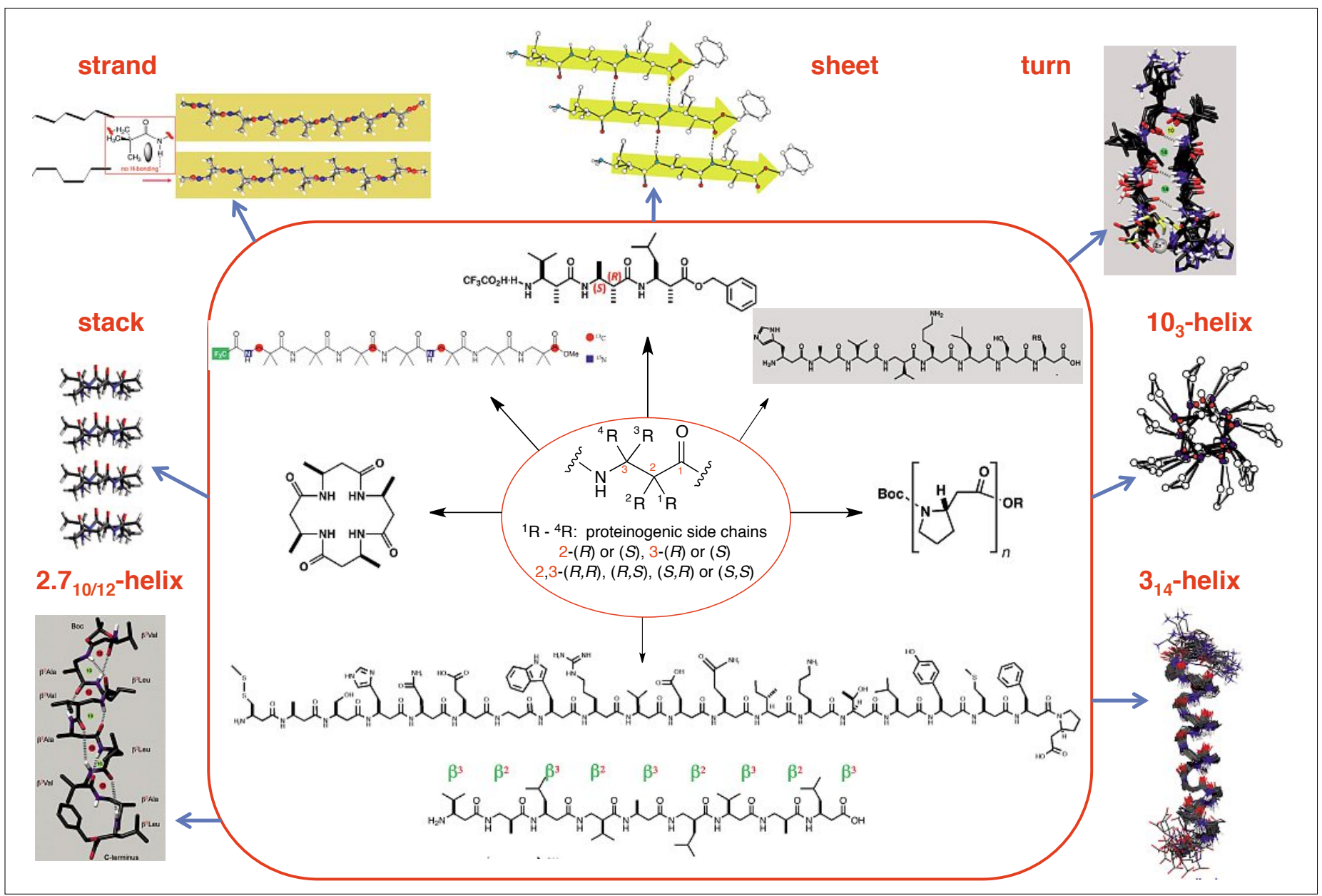

Fig. 4. Various types of $\beta$-amino acids (center), various residue sequences and the corresponding structures of $\beta$-peptides with proteinogenic side chains. ${ }^{[10]}$ 


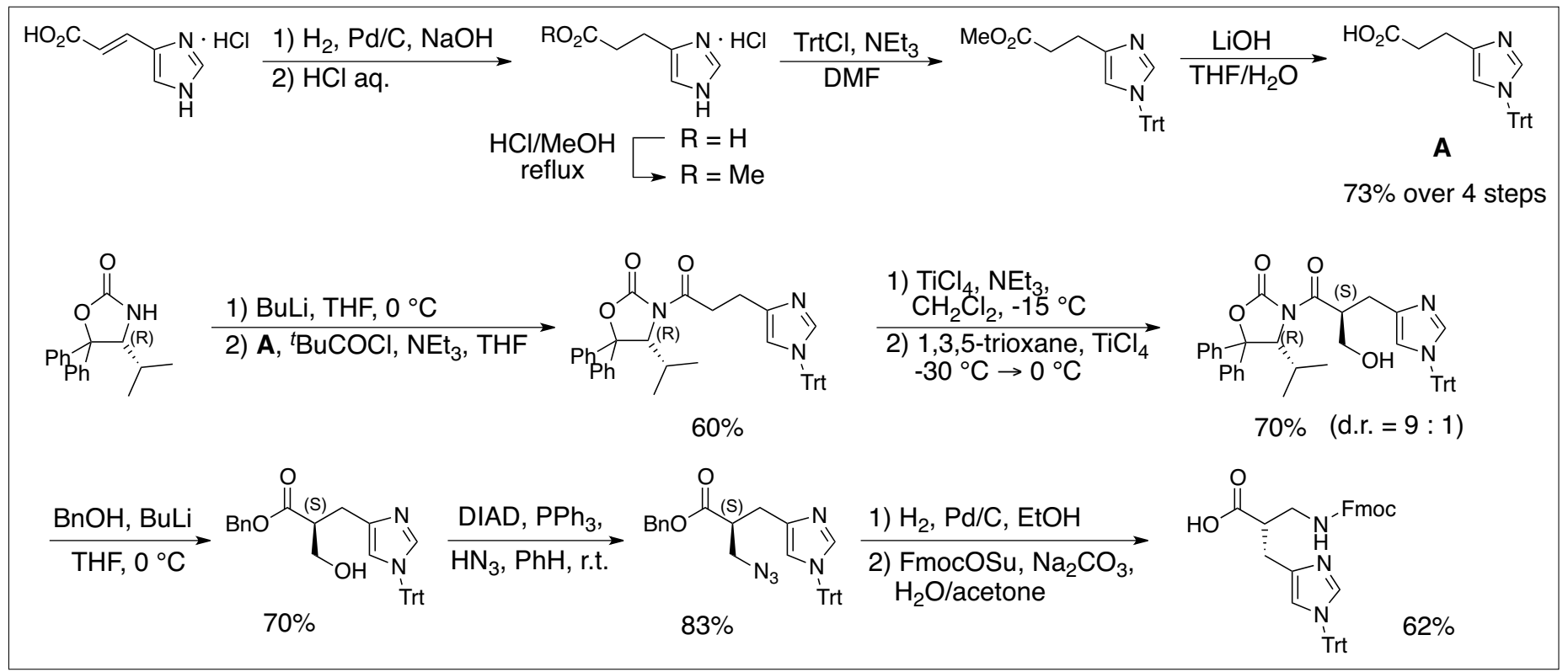

Fig. 5. Preparation of Fmoc- $\beta^{2} \mathrm{~h}-\mathrm{His}\left(\right.$ Trit)-OH from des-amino-histidine ${ }^{[12 a]}$ in eight steps (overall yield $11 \%$ ), using the modified Evans auxiliary with 5.5-diphenyl-substitution on the oxazolidinone ring (DIOZ $\left.{ }^{[12 b]}\right)$.

rodipole destabilization of the $\beta$-peptidic $3_{14}$-helix. Furthermore, a peculiar, novel type of $2.7_{10 / 12}$-helix is formed by sequences of alternating $\beta^{2}$ - and $\beta^{3}$-aminoacid residues, with no resulting macrodipole, consisting of narrow 10-membered and wider 12-membered hydrogen bonded pitches. After a learning process of approximately eight years between discovery[14] and a comprehensive review ${ }^{[10 b]}$ we were able to create these secondary structures by design.

\section{Biological Investigations}

The $\beta$ - and $\gamma$-amino acid residues of the new peptides do not fit into active sites of peptidases or metabolizing enzymes (Fig. 6). Thus, like $\alpha$-D-peptides, ${ }^{[15]}$ the $\beta$-peptides are excreted unchanged after administration to mammals, ${ }^{[10 b, 16]}$ suggesting that there is no interaction of $\beta$-peptides with proteins (PPI), i.e. with the active sites of proteases and metabolizing enzymes. In fact, there can be no mixed $\alpha / \beta$-peptide sheet or helical zipper ${ }^{[17]}$ (Fig. 7a). On the other hand, structurally not so strictly defined interactions, such as polar binding of anchoring groups in pockets, hydrophobic binding of amphipathic helices in non-polar grooves, or 'face-to-face' interactions between large surface areas of proteins and their ligands can be mimicked with $\beta$-peptides (Fig. 7b), see a review article entitled ' $\beta$-Peptidic Peptidomimetics'. ${ }^{[18]}$ Another biological process, in which no PPI is involved, is the cell penetration of polycationic peptides (CPPs) and other polyelectrolytic compounds. Nature uses this surprising effect for carrying proteins (cf. HIV-Tat) into cells, most commonly

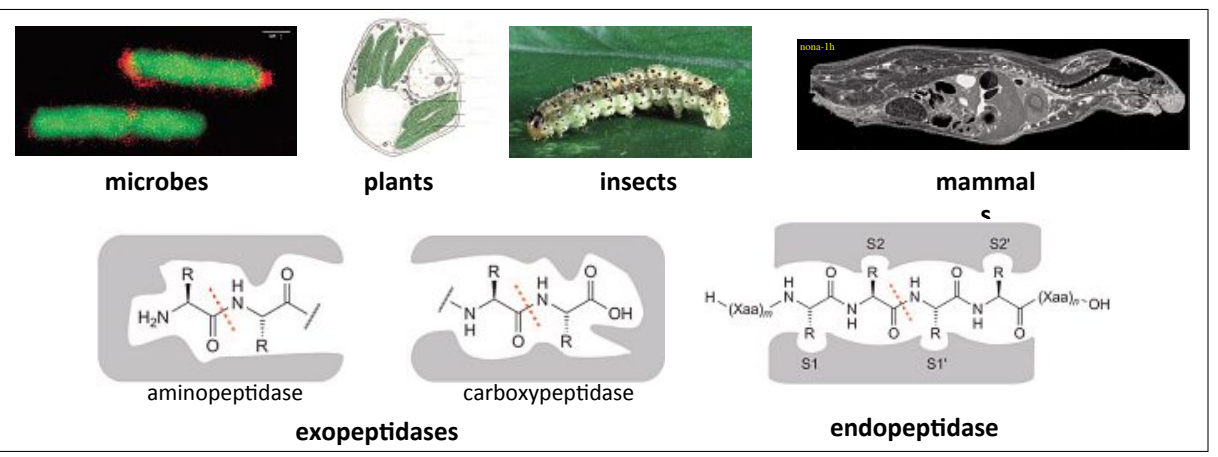

Fig. 6. $\beta$-Peptides are stable in essentially all organisms tested so far (for an exception see Fig. 11). The $\beta$-amino-acid residues are not recognized by exo- or endo-peptidases, or by metabolizing enzymes (cf. glucuronylation in insects), see section 10 in the review article in ref. [10b], and ref. [16].

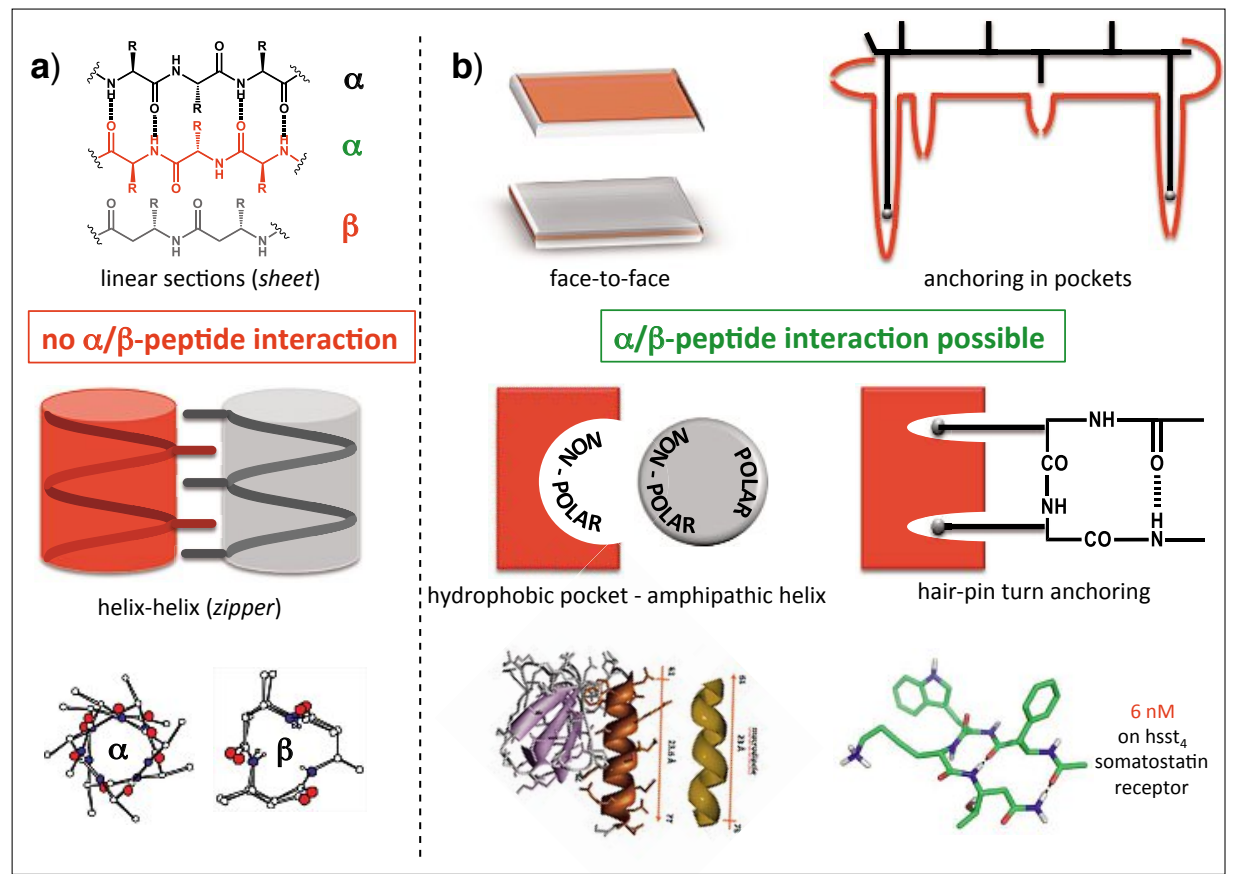

Fig. 7. Peptide-peptide and peptide-protein interactions (PPIs). a) Mixed $\alpha / \beta$-peptide sheets or zippers are structurally 'forbidden'. b) Possible PPIs between $\beta$-peptides and protein receptors (examples are the binding of $\beta$-peptidic ligands to CD40, MHCs, GPCRs, SR-B1, hDM2 receptors and the helix-protein interaction in hIL-8, see refs [10b] and [18] and references cited therein). 
with arginine-rich peptide sequences. In spite of numerous investigations into the mechanism, the details are still being discussed. Since the polycationic species, such as oligoarginines, do not pass the phospholipid bilayer of vesicles, which are often used as simple models for cell walls, since no trans-membrane transporter is involved, and since endocytotic entry was excluded in many cases, the potential across the cell wall, generated by proton and ion pumps, was proposed to play a major role. ${ }^{[19]}$ Amidinium and guanidinium ions are known ${ }^{[20]}$ to form thermodynamically stable salts with carboxylates ( $c f$. phosphatidylserine), phosphates ( $c f$. phospholipids) and sulfates ( $c f$. heparan sulfate) (Fig. 8), and formation of polycation-counterion complexes of this type is considered decisive for cell penetration. ${ }^{[21]}$

$\beta$-Oligoarginines ( $\beta$-OAs) appear to enter eukaryotic cells especially fast (Fig. 9b), ${ }^{[10 \mathrm{~b}]}$ which may be due to the fact that in a strand conformation the positively charged side chains, repelling each other, are all on the same face of the chain, which should lead to a higher affinity for lipophilic counterions (Fig. 9a). Like $\alpha$-OAs the

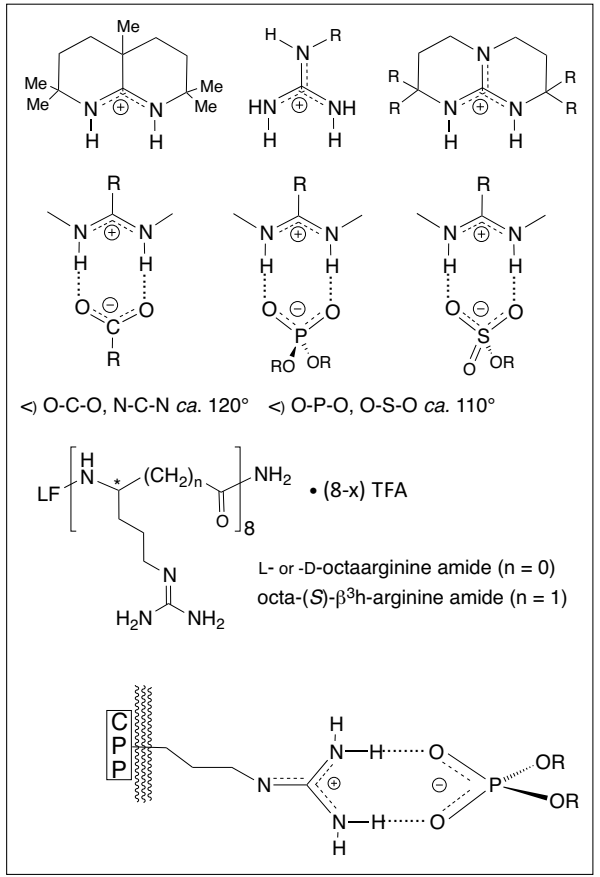

$\beta$-AOs do not enter healthy erythrocytes but infected ones, ${ }^{[22 a]}$ and they are able to penetrate through the most elaborate cell walls of mycobacteria (Fig. 9c) and para-
Fig. 8. Carboxylate, phosphate and sulfate salts ('adducts') of amidinium and guanidinium cations ${ }^{[20]}$ are involved in the cell penetration of oligoarginines, consisting of $\alpha$ - or $\beta$-arginine residues. ${ }^{[21]}$ The best fit between cation and anion is present with the carboxylate $\mathrm{r}_{\mathrm{H}, \mathrm{H}} \approx$ $\left.r_{0.0} \approx 2.2 \AA\right)$; in the phosphate and sulfate $r_{0,0}$ $\approx 2.4-2.5 \AA$. The oligoarginine derivatives employed in CPP investigations are TFA salts, as obtained in standard SPP syntheses.

sitic species to deliver drug cargoes ${ }^{[19 b, 22 b]}$ (Fig. 9). These microorganisms produce isoprenoids in a non-mevalonate pathway, the DXR enzyme of which is inhibited by fosmidomycin or FR-900098 (natural antibiotics). Structural investigations (X-ray, $\mathrm{NMR}^{[23]}$ ) of the complexes of DXR with fosmidomycin, a 2-valent cation, and NADPH have shown that the antibiotic is totally embedded by the enzyme, i.e. it has to be released from a CPP in order to be active. We have recently shown that a salt formed from an octaarginine and fosmidomycin (1:4) is highly active against the malaria parasite in vitro (Fig. 9d), and that even a covalently attached OA conjugate of FR-900098 phosphonate diester $(\geq 5 \mu \mathrm{M})$ is able to inhibit M. bovis growth (Fig. 9e). ${ }^{[22 \mathrm{~b}]}$

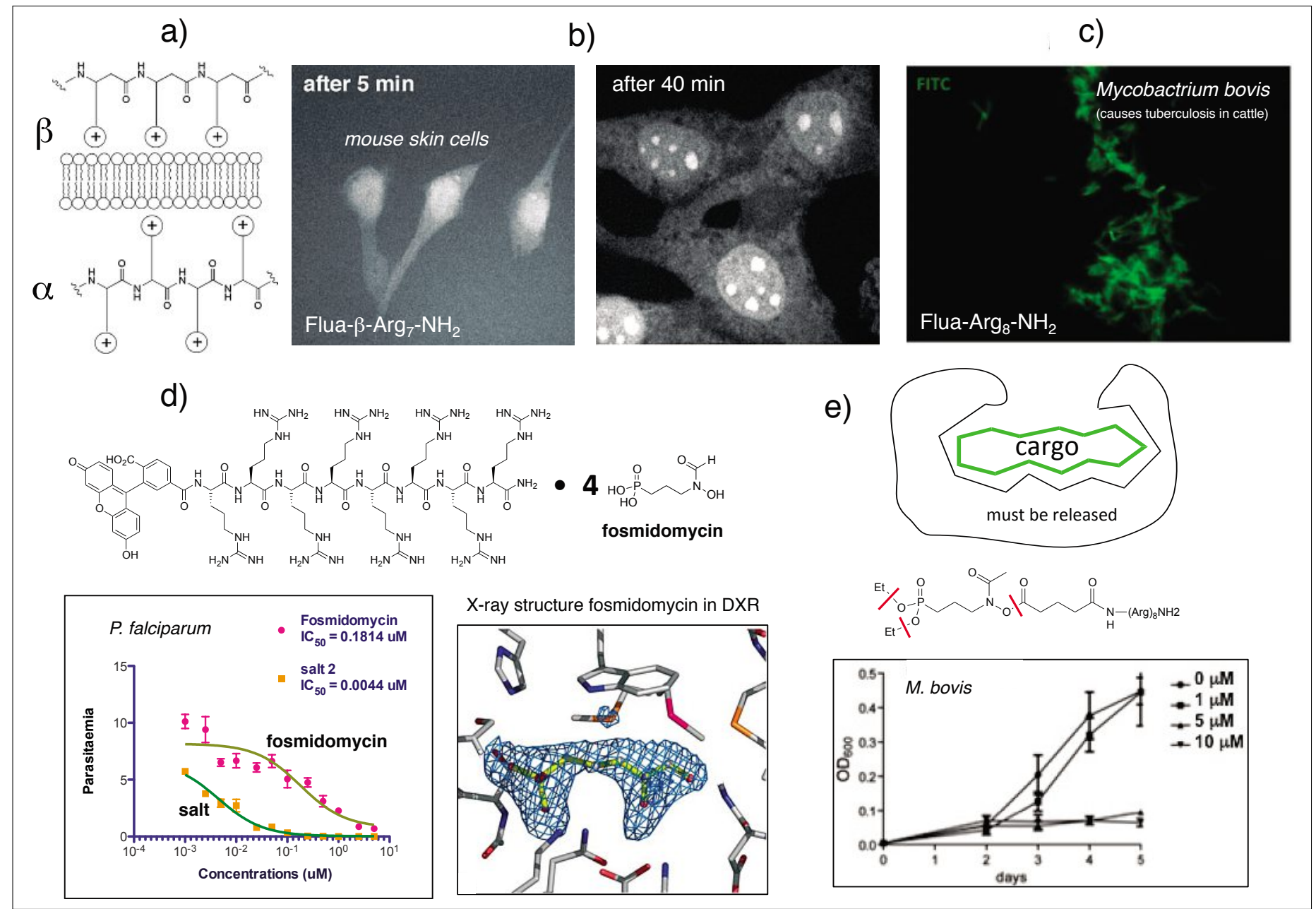

Fig. 9. Cell penetration of $\alpha$ - and $\beta$-oligoarginines (OAs) and delivery of antibiotics into plasmodium and mycobacterium species. a) Structural differences between $\alpha$ - and $\beta$-OA. b) Entry of $\beta-O A$ into the nucleus of skin cells. c) Fluorescence labeled $\alpha-O A$ having entered an $M$. tuberculosis species. d), e) Transport of fosmidomycin or FR-900098 into a parasite and into a mycobacterium with OA-conjugates. The presentations are partially taken from refs [10b], [22b] and [23a]. 
In the latter case the phosphonate ester and the $\mathrm{O}$-acyl bonds must be hydrolyzed before binding to DXR can occur. For in vivo investigations L-OA-derivatives are unsuitable because they are quickly degraded, D- and $\beta$-OAs are possibly too stable; modulation of enzymatic stability and other properties of OAs is, however, possible with mixed L/D-OAs. ${ }^{[24]}$ In these recent studies we have totally moved away from $\beta$-amino acids and $\beta$-peptides!

Besides OAs, we also studied L-, D-, $\beta^{2}$-, and $\beta^{3}$-oligoprolines (OPs) as cellpenetrating and phospholipid bilayer passing peptides. ${ }^{[25]}$ They enter HFF cells much more slowly $\left(12 \mathrm{~h} / 37^{\circ} \mathrm{C}\right)$ than the AOs and, being lipophilic, use endocytotic pathways. For measurement of the structure-dependent bilayer membrane translocation of the OPs we used the nanoFAST chip technology, by which the rate of permeation (molecules/ $\left(\mathrm{s} \cdot \mu_{\mathrm{m}}^{2}\right)$ ) can be determined simultaneously for hundreds of cavities. Whether oligoprolines can be used to carry cargoes other than fluorescent labels into cells remains to be determined.

The use of single $\beta$-amino-acid residues for protection of peptides against exopeptidases was demonstrated with the $C$-terminal, fully active neurotensin segment NTS(8-13). The neurotensin GPC receptor family NT1-3 is present in the brain and in the digestive system, and NTS modulates numerous processes related to dopamine neurotransmission, analgesia, inhibition of food intake, growth of cancer cells etc. ${ }^{[26]}$ For diagnostic and therapeutic applications the peptidolytic stability of NTS and other physiologically active peptides has to be increased with as little loss of activity as possible. The degradation by exo-peptidases is commonly inhibited by various structural modifications (Fig. 10a), which cause serious changes of the chemical properties and structures. ${ }^{[27]}$ In contrast, terminal homologation leaves the entire peptide chain from the $N$ - to the $C$-terminal stereocenter unscathed and preserves the terminal $\mathrm{NH}_{3}{ }^{+}$and $\mathrm{CO}_{2}{ }^{-}$charges, which are just shifted by one $\mathrm{C}, \mathrm{C}$-bond distance. In the case of NTS(8-13) the plasma stability increases from minutes to many hours and days after single and double terminal homologation (Fig. 10b), with almost complete retention of receptor affinity.[27,28]

Finally, we have discovered a unique type of enzyme, as a result of concern of youngsters in the group, asking whether $\beta$-peptides would ever disappear when put into a natural environment. Samples were collected from flowerpots, forests, fields, compost heaps and water-treatment plants. It took a year until we found a sample (from the sewerage plant of Leutschenbach, a suburb of Zurich), which showed very slow growth of a colony of microbes on the $\beta$-tripeptide ${ }^{+} \mathrm{H}_{2}-\beta^{3} \mathrm{hVal}$ -

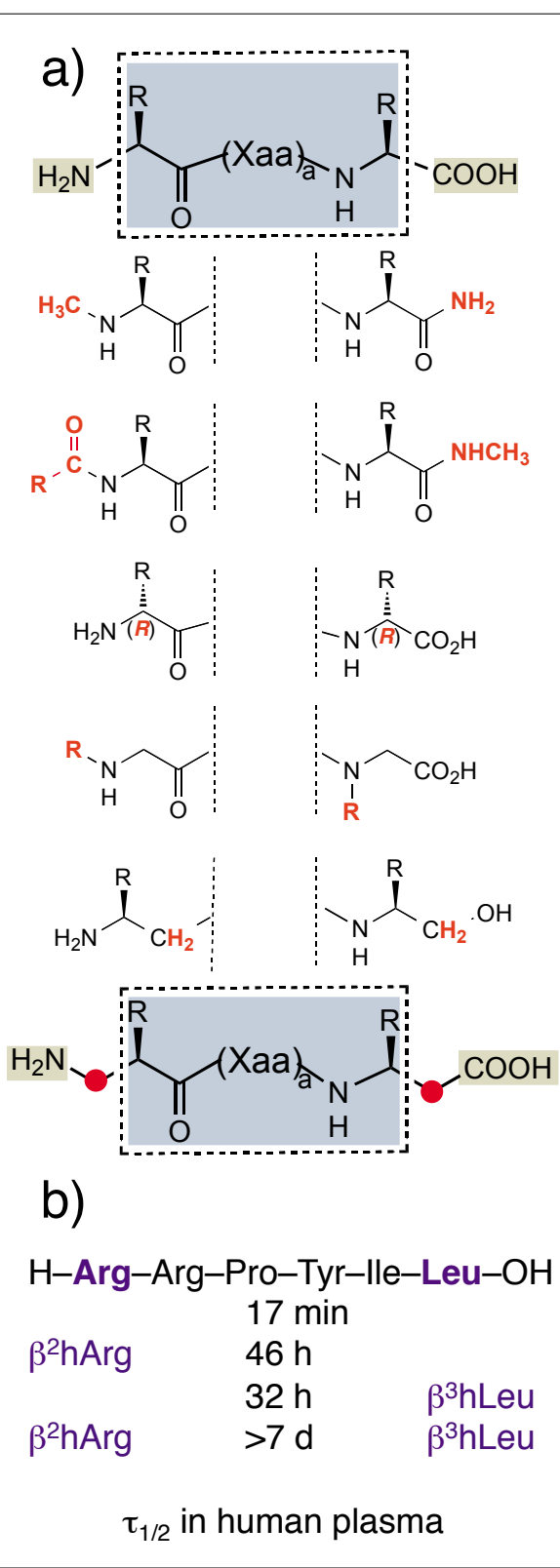

Fig. 10. Terminal protection of peptides against exo-peptidases by chemical modifications. a) Commonly applied methods and the new terminal homologation by replacing the $N$ - and/or the $C$-terminal residue by a $\beta^{2}$ - and a $\beta^{3}$-aminoacid residue, respectively. b) Effect on plasma stability of terminal homologation of NTS(8-13); the doubly homologated derivative has full affinity as agonists of the NT1 receptor in human cancer tissues. ${ }^{[27]}$

$\beta^{3}$ hAla- $\beta^{2} \mathrm{hLeu}^{-} \mathrm{O}^{-}$as the single carbon and energy source. Only one of the organisms in the colony (Sphingosinicella xenopeptidilytica sp. 3-2W4) was actually able to cleave the $\beta$-peptide, releasing products of degradation for the others to survive in a symbiosis (Fig. 11a). ${ }^{[10 b, 29 a]}$ To make a 12-year-long story short: the $\beta$-peptidecleaving enzyme (BapA) was isolated, its encoding gene cloned in $E$. coli to prepare larger quantities, its activity tested with a variety of substrates, and its X-ray crystal structure determined ${ }^{[29 b]}$ (Fig. 11). The results are published in $\mathrm{ca} .20$ papers. ${ }^{[29 c]}$ The $\beta$-peptidyl aminopeptidase BapA belongs to the well-known group of so-called $\mathrm{N}$-terminal nucleophile (Ntn) hydrolases, only five of which have now been identified as $\beta$-amino-peptidases. Our BapA enzyme has the peculiar property of accepting all $N$-terminal $\beta$-amino-acid residues (small, large, non-polar, polar, except for $\beta$-Asp and $\beta$-Glu), with a large pocket for the side chains in the active site, as if it were constructed for non-selective degradation of $\beta$-peptides (which have not been detected in nature!). BapA stops cleaving when it arrives at an $\alpha$-amino-acid residue in a mixed $\beta / \alpha$-peptide, opposite to all 'normal' amino peptidases, which stop with the first $\beta$-amino-acid residue in an $\alpha / \beta$-peptide. ${ }^{[30]}$

\section{Back to Organic Synthesis}

With the BapA enzyme available on larger scale we have tested it for synthetic purposes: BapA is capable of coupling a $\beta$-amino acid to an $\alpha$-amino acid, it cleaves $(S)-\beta^{2}$ hPhe-OH from a rac- $\beta$-peptide, ${ }^{[29 c]}$ and it can be used for preparative kinetic resolutions, for instance of rac- $\beta$-aminoacid amides to give the enantiopure $(S)$ acid and (R)-amide (Fig. 11d). ${ }^{[29 c, 31]}$ Thus our journey has taken us far into biological, pharmacological and biomedical research areas and back to - enzymatic - organic synthesis.

\section{Conclusion}

The story I have told herein is a demonstration of the statement about curiositydriven research: "One can certainly plan research, but not the result". ${ }^{[32]}$ For me and my collaborators this trip was a lot of fun and a constant process of learning about the miraculous chemistry of life.

\section{Acknowledgements}

I thank all my companions during the journey (master and $\mathrm{PhD}$ students, postdoctoral coworkers, visiting scholars, collaborators within and without ETH Zürich) for their contributions. Without their enthusiasm, dedication, and perseverance we would not have arrived where we are now, in the fascinating field of biomedical research. This arrival coincides with the end of my career as an experimental scientist, closing down my laboratory. The most generous financial support provided for more than 35 years by ETH Zürich, by the Swiss National Science Foundation, and by the Sandoz and Novartis companies is gratefully acknowledged. A special thank goes to my friend Albert Beck, who literally stood by my side for 50 years. ${ }^{[33]}$

Received: September 2, 2013 


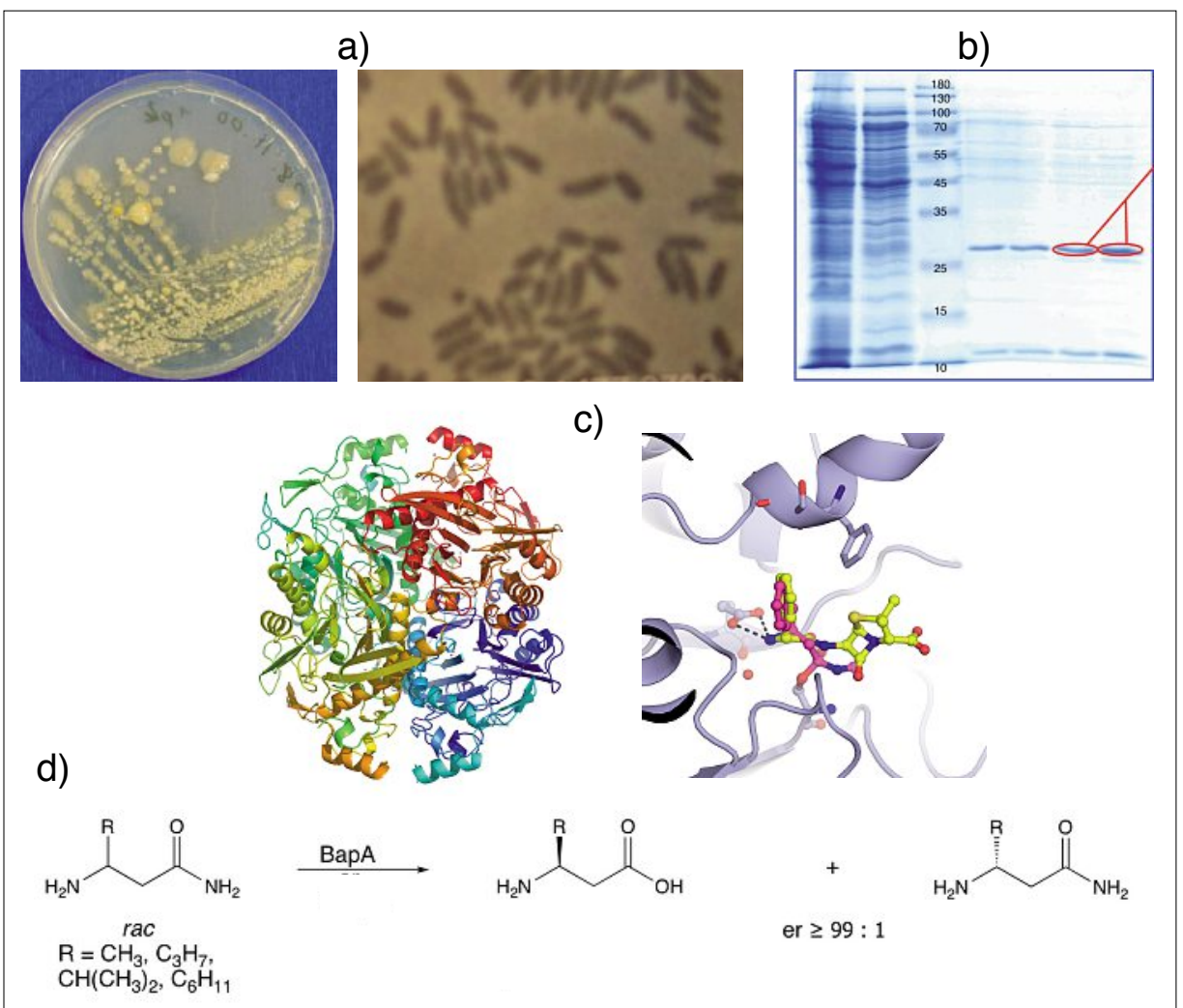

Fig. 11. Discovery of the microorganism Sphingosinicella xenopeptidilytica 3-2W4 and its $\beta$-peptide-cleaving enzyme BapA. ${ }^{[2]}$ a) In a symbiotic colony of microorganisms the species containing the Ntn hydrolase BapA was identified. b) Isolation of the enzyme and preparation by $E$. coli was followed by c) crystallization, by co-crystallization (cf. with antibiotic $\beta$-lactams, which inhibit BapA, but are not cleaved by it), and X-ray structural analyses (also of precursors and mutants of the enzyme). d) BapA can be used for the preparation of $\beta$-amino acids by enzymatic kinetic resolution.

[1] a) D. Seebach, 'How I became a Peptide Chemist', Lonza Brochure, Lonza Ltd. Basle, 1990; b) D. Seebach, 'How We Stumbled Into Peptide Chemistry', Aldrichimica Acta 1992, 25,$59 ;$ c) D. Seebach, A. Beck, M. Rueping, J. V. Schreiber, H. Sellner, 'Excursion of Synthetic Organic Chemists to the World of Oligomers and Polymers', Chimia 2001, 55, 98; d) D. Seebach, M. Albert, P. I. Arvidsson, M. Rueping, J. V. Schreiber, 'From the Biopolymer PHB to Biological Investigations of Unnatural $\beta$ - and $\gamma$-Peptides', Chimia 2001, 55, 345; e) D. Seebach, A. K. Beck, M. Brenner, C. Gaul, A. Heckel, 'From Synthetic Methods to $\gamma$-Peptides - From Chemistry to Biology', Chimia 2001, 55, 831; f) T. Kimmerlin, R. Šebesta, M. A. Campo, A. K. Beck, D. Seebach, 'How we drifted into peptide chemistry and where we have arrived at', Tetrahedron 2004, 60, 7455.

[2] D. Seebach, H.-O. Kalinowski, 'Enantiomerenreine Naturstoffe und Pharmaka aus billigen Vorläufern (Chiral Pool)', Nachr. Chem. Techn. 1976, 24,415 .

[3] a) H.-M. Müller, D. Seebach, Angew. Chem. 1993, 105, 483; Angew. Chem. Int. Ed. Engl. 1993, 32, 477; b) D. Seebach, A. Brunner, B. M. Bachmann, T. Hoffmann, F. N. M. Kühnle, U. D. Lengweiler, Ernst Schering Research Foundation, 1995, 28, 7; c) D. Seebach, M. G. Fritz, 'Detection, synthesis, structure, and function of oligo-(3-hydroxyalkanoates): contributions by synthetic organic chemist', Int . J. Biol. Macromol. 1999, 25, 217.

[4] D. Seebach, E. Hungerbühler, 'Syntheses of Enantiomerically Pure Compounds (EPCSyntheses) - Tartaric Acid, an Ideal Source of Chiral Building Blocks for Syntheses?' in
'Modern Synthetic Methods', Ed. R. Scheffold, Salle + Sauerländer, Frankfurt/Aarau, 1980, 91 .

[5] D. Seebach, H.-F. Chow, R. F. W. Jackson, K. Lawson, M. A. Sutter, S. Thaisrivongs, J. Zimmermann, J. Am. Chem. Soc. 1985, 107, 5292.

6] D. Seebach, P. B. Rheiner, G. Greiveldinger, T Butz, H. Sellner, 'Topics in Current Chemistry: Dendrimers', Ed. F. Vögtle, Springer Verlag Berlin, Heidelberg 1998, 197, 125.

[7] a) D. Seebach, A. R. Sting, M. Hoffmann, Angew. Chem. 1996, 108, 2880; Angew. Chem. Int. Ed. Engl. 1996, 35, 2708; b) B. Jaun, M. Tanaka, P. Seiler, F. N. M. Kühnle, C. Braun, D. Seebach, Liebigs Ann./Recueil 1997, 1697.

[8] a) E. Hungerbühler, D. Seebach, D. Wasmuth, Helv. Chim. Acta 1981, 64, 1467; D. Seebach, J. Aebi, D. Wasmuth, Organic Syntheses $\mathbf{1 9 8 5}$, 63, 109; Collective Volume VII, 1990, 153, b) D. Seebach, J. Zimmermann, U. Gysel, R. Ziegler, T.-K. Ha, J. Am. Chem. Soc. 1988, 110, 4763 c) H. Estermann, D. Seebach, Helv. Chim. Acta 1988, 71, 1824; T. Yoshinari, F. Gessier, C. Noti, A. K. Beck, D. Seebach, Helv. Chim. Acta 2011, 94, 1908; d) D. Seebach, R. Naef, Helv. Chim. Acta 1981, 64, 2704; e) D. Seebach, A. Boog, W. B. Schweizer, Eur. J. Org. Chem. 1999, 335.

[9] R. N. Reusch, 'Physiological Importance of Poly-(R)-3-hydroxybutyrates', Chem. Biodiv. 2012, 9, 2343.

[10] a) D. Seebach, J. L. Matthews, ' $\beta$-Peptides: a surprise at every turn': Chem. Commun. 1997, 2015; b) D. Seebach, A. K. Beck, D. J. Bierbaum, 'The World of $\beta$ - and $\gamma$-Peptides Comprised of Homologated Proteinogenic Amino Acids and Other Components', Chem.
Biodiv. 2004, 1, 1111, and references cited therein.

[11] R. P. Cheng, S. H. Gellman, W. F. DeGrado, ' $\beta$-Peptides: From Structure to Function', Chem. Rev. 2001, 101, 3219.

[12] a) G. Lelais, P. Micuch, D. Josien-Lefebvre, F. Rossi, D. Seebach, Helv. Chim. Acta 2004, 87, 3131; b) D. Seebach, A. K. Beck, S. Capone, G. Deniau, U. Grošelj, E. Zass, 'Enantioselective Preparation of $\beta^{2}$-Amino Acid Derivatives for $\beta$-Peptide Synthesis', Synthesis 2009, 1.

[13] D. Seebach, D. F. Hook, A. Glättli, 'Helices and Other Secondary Structures of $\beta$ - and $\gamma$-Peptides', Biopolymer (Peptide Science) 2006, 84,23

[14] D. Seebach, M. Overhand, F. N. M. Kühnle, B. Martinoni, L. Oberer, U. Hommel, H. Widmer, Helv. Chim. Acta 1996, 79, 913.

[15] J. R. Pappenheimer, M. L. Karnovsky, J. E. Maggio, J. Pharmacol. Exp. Ther. 1997, 280, 292.

[16] H. M. Weiss, B. Wirz, A. Schweitzer, R Amstutz, M. I. R. Perez, H. Andres, Y. Metz, J. Gardiner, D. Seebach, Chem. Biodiv. 2007, 4, 1413.

[17] Certain mixed $\alpha / \beta$-peptides fold to helices, which can actually pack with an $\alpha$-peptidic helix: J. L. Price, E. B. Hadley, J. D. Steinkruger, S. H. Gellman, Angew. Chem. 2010, 122, 378; Angew. Chem. Int. Ed. Engl. 2010, 49, 368; J. L. Price, W. S. Horne, S. H. Gellman, J. Am. Chem. Soc. 2010, 132, 12378

[18] D. Seebach, J. Gardiner, ' $\beta$-Peptidic Peptidomimetics', Acc. Chem. Res. 2008, 41, 1366.

[19] a) R. B. Rothbard, T. C. Jessop, R. S. Lewis, B. A. Murray, P. A. Wender, J. Am. Chem. Soc. 2004, 126, 9506; b) E. Geihe Stanzl, B. M. Trantow, J. R. Vargas, P. A. Wender, 'Fifteen Years of Cell-Penetrating, GuanidiniumRich Molecular Transporters: Basic Science, Research Tools, and Clinical Applications', Acc. Chem. Res. 2013, doi: 10.1021/ar4000554.

[20] a) F. Heinzer, M. Soukup, A. Eschenmoser, Helv. Chim. Acta. 1978, 61, 2851; b) F. P. Schmidtchen, M. Berger, Chem. Rev. 1997, 97, 1609; c) P. Selig, Synthesis 2013, 45, 703.

[21] Y. Su, T. Doherty, A. J. Waring, P. Ruchala, M. Hong, Biochemistry 2009, 48, 4587; for authoritative reviews on the subject see [19b] and J. Montenegro, C. Gehin, E. K. Bang, A. Fin, D. A. Doval, H. Riezman, N. Sakai, S. Matile, 'Conceptually New Entries into Cells', Chimia 2011, 65, 853.

[22] a) F. Kamena, B. Monnanda, D. Makou, S. Capone, K. Patora-Komisarska, D. Seebach, Chem. Biodiv. 2011, 8, 1; b) C. Sparr, N. Purkayastha, B. Kolesinska, M. Gengenbacher, B. Amulic, K. Matuschweski, D. Seebach, F. Kamena, Antimicrob. Agents Chemother. 2013 , 57, 4689.

[23] a) A. M. Sweeney, R. Lange, R. P. M. Fernandes, H. Schulz, G. E. Dale, A. Douangamath, P. J. Proteau, C. Oefner, J. Mol. Biol. 2005, 345 , 115 ; b) N. E. Englert, C. Richter, J. Wiesner, M. Hintz, H. Jomaa, H. Schwalbe, ChemBioChem 2011, 12, 468, and references cited therein.

[24] N. Purkayastha, K. Eyer, T. Robinson, P. S. Dittrich, A. K. Beck, D. Seebach, B. Kolesinska, R. Cadalbert, Chem. Biodiv. 2013, 10, 1165.

[25] B. Kolesinska, D. J. Podwysocka, M. A. Rueping, D. Seebach, F. Kamena, P. Walde, M. Sauer, B. Windschiegl, M. Meyer-Ács, M. Vor der Brüggen, S. Giehring, Chem. Biodiv. 2013, $10,1$.

[26] a) R. E. Carraway, A. M. Plona, Peptides 2006, 27, 2445; b) J. F. White, N. Noinaj, Y. Shibata, J. Love, B. Kloss, F. Xu, J. GvozdenovicJeremic, P. Shah, J. Shiloach, C. G. Tate, R. Grisshammer, Nature 2012, 490, 508 and comprehensive referencing therein.

[27] a) D. Seebach, A. Lukaszuk, K. Patora- 
Komisarska, D. Podwysocka, J. Gardiner, M.O. Ebert, J. C. Reubi, R. Cescato, B. Waser, P. Gmeiner, H. Hübner, C. Rougeot, Chem. Biodiv. 2011, 8, 711, and ref. [2], [4], [9] cited therein; b) A. Lukaszuk, H. Demaegdt, E. Szemenyei, G. Tóth, D. Tymecka, A. Misicka, P. Karoyan, P.Vanderheyden, G. Vauquelin, D. Tourwé, $J$. Med. Chem. 2008, 51, 2291.

[28] C. Sparr, N. Purkayastha, T. Yoshinari, B. Kolesinska, J. C. Reubi, P. Gmeiner, H. Hübner, O. Prante, S. Maschauer, D. Seebach, hitherto unpublished work at ETHZ, Universität Bern and FAU Erlangen; Chem. Biodiversity 2013, in print.

[29] a) J. V. Schreiber, J. Frackenpohl, F. Moser, T. Fleischmann, H.-P. Kohler, D. Seebach, ChemBioChem 2002, 3, 424; b) T. Heck, T. Merz, A. Reimer, D. Seebach, D. Rentsch, C. Briand, M. G. Grütter, H.-P. E. Kohler, B. Geueke ChemBioChem 2012, 13, 2137; c) Reviews: B. Geueke, H.-P. E. Kohler, 'Bacterial $\beta$-peptidyl aminopeptidases: on the hydrolytic degradation of $\beta$-peptides', Appl. Microbiol. Biotechnol. 2007, 74, 1197; c) T. Heck, B. Geueke, H.-P. E. Kohler, 'Bacterial $\beta$-Aminopeptidases: Structural Insights and Applications for Biocatalysis', Chem. Biodiv. 2012, 9, 2388 .

[30] T. Heck, M. Limbach, B. Geueke, M. Zachariasc, J. Gardiner, H.-P. E. Kohler, D. Seebach, Chem. Biodiv. 2006, 3, 1325; D. F. Hook, P. Bindschädler, Y. R. Mahajan, R. Šebesta, P. Kast, D. Seebach, Chem. Biodiv. 2005, 2, 591.

[31] T. Heck, D. Seebach, S. Osswald, M. K. J. ter Wiel, H.-P. E. Kohler, B. Geueke, ChemBioChem 2009, 10, 1558.

[32] D. Seebach, 'Organic Synthesis - Where now?', Angew. Chem. 1990, 102, 1363; Angew. Chem. Int. Ed. 1990, 29, 1320.

[33] a) A. K. Beck, Helv. Chim. Acta 2012, 95, 2304; b) D. Seebach, Chimia 2007, 61, 51. 